\title{
Development and Structural Behaviour of Soybean Gelato
}

\author{
Juliana Savio ', Daiane Preci', \\ Murilo Castelle², Alexandra \\ Manzolli', llizandra \\ Aparecida Fernandes', \\ Alexander Junges ${ }^{1}$, Rosicler \\ Colet $^{1}$, Mercedes Carrão- \\ Panizzi ${ }^{3}$, Cecilia Abirached ${ }^{4}$, \\ Juliana Steffens ${ }^{1 *}$ and \\ Eunice Valduga ${ }^{1}$
}

'Department of Food Engineering, URI Erechim, Av. Sete de Setembro 1621, Erechim, Brazil, 99709-910 ${ }^{2}$ Department of Food EngineeringUnochapecó, Avenida Senador Attílio Fontana, 591-E, Efapi, Chapecó, Brazil, 89809-900

${ }^{3}$ Brazilian Agricultural Research Corporation. Rodovia BR 285, Km 294, Passo Fundo, Brazil, 99050-970 ${ }^{4}$ Department of Food Science and Technology, Facultad de Química, Universidad de la República, Av. General Flores 2124, Montevideo, Uruguay, 11800

Received: 6 February 2018 Accepted: 24 October 2018

\section{(i) ()}

\section{SUMMARY}

The aim of this study is to elaborate and evaluate structural characteristics of soybean gelato by varying the content of soybean protein concentrate ( 2.95 to $17.05 \%$ ) and vegetable fat ( 7.95 to $22.05 \%$ ) using experimental design. The replacement of milk by hydrosoluble extract and soybean protein concentrate presented itself as an alternative to gelato production with unique characteristics, especially in terms of protein, solubility, viscosity, melting point, overrun and acceptability. The addition of up to $5 \%(\mathrm{~m} / \mathrm{M})$ protein concentrate, $14 \%$ (by volume) soybean hydrosoluble extract, and $15 \%$ (by mass) vegetable fat to gelato formulations resulted in better structural characteristics, with viscosity ranging from $0.45-0.70 \mathrm{~Pa} \cdot \mathrm{s}$ at $10^{\circ} \mathrm{C}$, a non-Newtonian behaviour and protein stability (total protein content $8.44 \%$ and solubility $41 \%$ ). Soybean gelato structural analysis using X-ray diffraction revealed $15^{\circ}$ and $35^{\circ}$ diffraction angles at $2 \Theta$, characterizing the crystalline part of the product. The thermal analyses showed four bands of mass loss in the temperature range of $40-600{ }^{\circ} \mathrm{C}$, characterizing loss of moisture, decomposition of the soy protein and the fat/ emulsifier of the formulations. Thus, the soybean gelato is an innovative product, lactose and milk protein-free with outstanding characteristics for the general public, mainly, for the populations with intolerance to such components.

Key words: gelato, soybean, viscosity, crystallinity, solubility, stability

\section{INTRODUCTION}

The food industry commercializes in natura soybean grains, it also produces various soybean-based products, such as soybean concentrates or isolates, textured soybean, oil, fermented foods (miso, soy sauce, and tempeh), hydrosoluble soybean extract, as well as non-fermented foods such as tofu, flour, soy bran and okara (1-4). Protein and oil content are not only adequate but also rated as the best in terms of quality. Soy milk is cholesterol-free and has high levels of unsaturated fatty acids, such as linoleic and linolenic acids, which is considered highly healthy (5).

Hydrosoluble extract and/or soybean protein concentrate are derivatives with great potential for creating distinctive products that could be used as a milk replacement for various formulations with several advantages. One of them is the non-existence of lactose, which may cause food rejections due to intolerance issues $(6,7)$. It can also prevent degenerative chronic diseases by the action of phytochemicals (isoflavones) and some cancer types, and reduce cholesterol $(8,9)$.

However, limited reports exist on the role of soy protein concentrate addition in ice cream. Soy proteins provide several functionalities such as high emulsifying properties, stability, water-holding and binding capacity $(10,11)$, thus providing an array of food products, such as ice cream and/or gelato. The use of foods fortified with soy protein concentrate is an approach that could provide additional health benefits in a well-accepted food such as ice cream. The use of soy proteins to alter the ice cream product physicochemical and sensory properties has been reported (12-14).

Food industries such as ice cream have been expanding their market with new products such as gelato, which has been constantly approved by the public. Gelato is ice cream 
variation with more creaminess and less fat. In this context, the preparation of soybean products such as gelato is an innovative alternative to ice cream, adding value to soybean, with functional properties and specific structural characteristics.

\section{MATERIALS AND METHODS}

\section{Obtaining hydrosoluble extract and soybean protein concentrate}

The soybean (Glycine max) BRS 267 cultivar (2012/2013 harvest) used in this work was obtained from Embrapa Trigo, Passo Fundo, RS, Brazil. Soybean hydrosoluble extract was obtained according to the method of Mandarino et al. (15), with modifications. Initially, soybean grains were macerated in water at a 1:4 $(\mathrm{m} / \mathrm{V})$ ratio, and kept at boiling point $\left(97^{\circ} \mathrm{C}\right)$ for $5 \mathrm{~min}$. Then, soybean maceration water was drained out. After that, soybean grains were mixed in boiling water at 1:1 $(\mathrm{m} / \mathrm{N})$ ratio for $5 \mathrm{~min}$, cooled to room temperature and dissolved using an industrial blender (Drink Machine, Equinox RS, Porto Alegre, Brazil). After disintegration, the contents were transferred to a basket centrifuge for separation at $156000 \times g$ (model 5403; Eppendorf, Denkendorf, Germany), obtaining the soybean hydrosoluble extract.

The soybean protein concentrate was obtained using soybean hydrosoluble extract which was dried by spray dryer (model SD-05; LabPlant, Filey, UK) at air temperature $190{ }^{\circ} \mathrm{C}$, air rate $47 \mathrm{~m}^{3} / \mathrm{h}$, and extract inlet rate $600 \mathrm{~mL} / \mathrm{h}$. The dried extract was stored in hermetically sealed amber flasks until used.

\section{Preparation of gelato formulations}

Gelato formulations were prepared based on preliminary tests and following the method of Maia et al. (16), with modifications. Using $2^{2}$ full factorial design, the following formulations were selected: soybean protein concentrate 2.95 to $17.05 \%(\mathrm{~m} / \mathrm{N})$ and hydrogenated vegetable fat (Elegê, São Paulo, Brazil) 7.95 to $22.05 \%(\mathrm{~m} / \mathrm{M})$. The fixed independent variables were soybean hydrosoluble extract (68\%), sucrose (União, Rio de Janeiro, Brazil) 10 $\%$, powder glucose (Nutre, São Paulo, Brazil) $5 \%$, stabilizer (Kerry, São Paulo, Brazil) 2 \% and emulsifier (Kerry, São Paulo, Brazil) $2 \%$.

Water, soybean hydrosoluble extract, sucrose, glucose, soybean protein, and hydrogenated vegetable fat were mixed to form syrup that was then pasteurized (model pp110; Arpifrio, São Paulo, Brazil) at $90^{\circ} \mathrm{C}$ for $25 \mathrm{~s}$. Afterwards, it was cooled to $4^{\circ} \mathrm{C}$ for $24 \mathrm{~h}$ for maturation and subsequently, a strawberry flavour (Duas Rodas, Jaraguá do Sul, Brazil) was added to it. Thereafter, it was homogenized for 5 min using an industrial blender (model BP 12, G Panis, Caxias do Sul , Brazil), then beaten using an industrial ice cream maker (model AA239; Fortfrio, Betin, Brazil), and cooled to $-3^{\circ} \mathrm{C}$. The gelato batter was stored in polypropylene packaging (Valpri, Campinas, Brazil) at $-20^{\circ} \mathrm{C}$.

The dependent variables (responses) of the $2^{2}$ full factorial design were: protein content, fat, overrun, specific mass, viscosity, functional properties (solubility and protein stability), crystallinity, melting point, and thermogravimetric analysis.

\section{Characterization of soybean protein concentrate and gelato formulations}

Protein, fat and moisture contents of soybean powder protein concentrate were characterized. Total protein, solubility, protein stability, fat, overrun, specific mass, viscosity, crystallinity and melting point of gelato formulations were also characterized, followed by thermogravimetric analysis.

Moisture was determined by oven (model MA035; Marconi, Piracicaba, Brazil) drying at $105^{\circ} \mathrm{C}$ with air circulation to a constant mass, and lipid content was obtained by extraction with petroleum ether in a Soxhlet-type extractor (model NT 340; Nova ética, Vargem Grande do Sul, Brazil) using the principles of gravimetric analysis. Total protein was calculated from the total nitrogen content using Kjeldahl method multiplied by factor 6.25, according to AOAC method 991.22 (17).

Solubility was determined by dispersion of $0.1 \%(\mathrm{~m} / \mathrm{M}) \mathrm{ge}$ lato powder in a $10 \mathrm{mM}$ phosphate buffer (Merck, Kenilworth, $\mathrm{NJ}, \mathrm{USA}$ ) at $\mathrm{pH}=7.0$, which was stirred on a high-speed mechanical stirrer (model GT-201BS; Kline, Monte Alto, Brazil) for $1 \mathrm{~h}$ at room temperature. After that, the samples were centrifuged (centrifuge model 5403; Eppendorf) at $10000 \times \mathrm{g}$ for $10 \mathrm{~min}$ at $4^{\circ} \mathrm{C}$. The protein content of the supernatant was determined at $750 \mathrm{~nm}$ using spectrophotometer (model 8553; Agilent, Santa Clara, CA, USA) by the method of Lowry et al. (18) using bovine serum albumin $1 \mathrm{mg} / \mathrm{L}$ as a standard.

The formulations were reconstituted in order to characterize the sample destabilization and to determine the functional properties of gelato. Then, $4.6 \mathrm{~g}$ per sample were prepared by adding $54 \mathrm{~mL}$ sodium phosphate buffer, $\mathrm{pH}=7$ (Merck). The emulsions were prepared at room temperature using an Ultraturrax T25 (IKA Labortechnik, Staufen, Germany) homogenizer with an S25 N-10 dispersant accessory at 20000 rpm for $1.5 \mathrm{~min}$. Stability was analysed using a vertical optical analyser (Turbiscan ${ }^{\text {TM }}$ Classic MA 2000; Formulaction, L'Union, France). The emulsions were placed in an $80-\mathrm{mm}$ cylindrical glass cell to register destabilization, depending on the cell height, measuring it every $15 \mathrm{~min}$ for $5 \mathrm{~h}$. Total destabilization was calculated at $40 \mathrm{~mm}$ of tube height using the following equation:

$$
\text { Destabilization }=\frac{\mathrm{RD}_{5}-\mathrm{RD}_{0}}{\mathrm{RD}_{0}}
$$

where $\mathrm{RD}_{0}$ and $\mathrm{RD}_{5}$ are backscattering at $40 \mathrm{~mm}$ tube height at times 0 and $5 \mathrm{~h}$.

The gelato viscosity at temperatures of 10 and $20^{\circ} \mathrm{C}$ was determined using a rotational viscometer (model 36123; AMETEK Brookfield, Middleboro, MA, USA). Melting point was determined according to the adapted method by Granger et al. (19). Initially, $100 \mathrm{~g}$ of ice cream was placed on a mesh grid (mesh size $1 \mathrm{~cm} \times 1 \mathrm{~cm}$ ) and the melted material was collected and weighed every $10 \mathrm{~min}$.

Overrun was measured after batch freezing by carefully filling a capsule of known volume with the ice cream and weighed. Comparisons of the original ice cream mixture mass allowed overrun calculation. 
Ice cream specific mass (density relative to water) was determined by glass pycnometer (Labor Quimi, Poá, Brazil) of 50 $\mathrm{mL}$. The pycnometer was first weighed empty, and then filled once with distilled water and once with ice cream at $25^{\circ} \mathrm{C}$ and mass was recorded each time.

Diffractograms were obtained using an X-ray diffractometer (XRD 6000; Shimadzu, Kyoto, Japan) with Cu-1.54 transmitter tube, in order to observe crystallinity peaks. The thermogravimetric analyses were performed on TGA device (model Q500; TA Instruments, New Castle, PA, USA). The sample of $11.7 \mathrm{mg}$ was placed in platinum pan and heated in nitrogen flow $\left(40 \mathrm{~cm}^{3} /\right.$ min), with a temperature range of $40-600^{\circ} \mathrm{C}$ with heating rates of $10^{\circ} \mathrm{C} / \mathrm{min}$ for each sample, and was determined by mass loss.

\section{Consumer acceptability}

Consumer acceptability of the ice creams was tested on a laboratory scale, with 36 panellists, professors, students, employees of the institution, male and female, age groups ranging from 20 to 50 . Affective tests served for sensory evaluation. The tests were performed on the samples within 1 week of storage. The panellists were asked to indicate how much they liked or disliked the ice creams based on the attribute global acceptance, according to a 9-point hedonic scale (9=extremely liked and $1=$ extremely disliked). Each sample was randomly coded with three-digit numbers. As the research involved humans, tests were performed according to the Research Ethics Committee of the Regional Integrated University of Upper Uruguay and Missions, and Brazilian National Health Council ethical and scientific requirements, registered at Plataforma Brasil (20) with the number CAAE 03496312.1.0000.521.

\section{Statistical analysis}

The results were statistically treated using analysis of variance (ANOVA), Tukey's test, Pearson's correlation, and principal component analysis (PCA), aided by Statistica v. 5.0 software (21) with 90 and/or $95 \%$ confidence level.

\section{RESULTS AND DISCUSSION}

Soybean hydrosoluble extract (32.06 \% total solids) and soybean powder protein concentrate contained 1.65 and 43.3 $\%$ (dry mass) of protein and 3.50 and $21 \%$ (dry mass) of fat, respectively.

Table 1 shows the $2^{2}$ full factorial design matrix with coded (real) values of independent variables studied on gelato formulations and dependent variables (response). Gelato formulation from run 6 had the highest total protein content and solubility. These results are better viewed in the following equations and the contour curves (Fig. 1):

$$
\begin{aligned}
& \mathrm{TP}=9.51+3.42 . \mathrm{X}_{1} \\
& \mathrm{PS}=41.11+1.29 . \mathrm{X}_{1}
\end{aligned}
$$

where TP is total protein, PS is protein solubility and $X_{1}$ is soybean protein concentrate (\%).

The addition of protein concentrate influenced significantly $(p<0.05)$ the protein content and solubility of soybean gelato formulations. The non-significant parameters were added to the lack of fit for the analysis of variance (ANOVA) test. Eqs. 1 and 2 give a second-order coded model describing total protein and solubility in terms of independent variables, within the studied ranges. The models were validated by ANOVA with a 0.93 and 0.95 coefficient correlation and $F$ calculated values 12 and 15 times greater than the $F$ tabulated ones, allowing the construction of contour curves shown in Figs. $1 \mathrm{a}$ and $1 \mathrm{~b}$, respectively. It is possible to see that the maximum for total protein and solubility is within the range of $15 \%$ soybean concentrated protein addition and at any hydrogenated vegetable fat mass per volume ratio.

According to Zayas (22), the solubility index may be used as a parameter for protein functionalities. Protein is of great importance for ice cream quality, as it affects the beating, emulsification, and it improves the ice cream structure (23). It also contributes to functional properties such as the interaction with other stabilizers, emulsion stabilization after

Table 1. Full factorial design $2^{2}$ (coded and real values) and responses on protein content, solubility, fat content, density $(\rho)$, melting point $\left(T_{\mathrm{m}}\right)$

\begin{tabular}{|c|c|c|c|c|c|c|c|c|}
\hline \multirow[b]{2}{*}{ Run } & \multicolumn{2}{|c|}{ Independent variable } & \multicolumn{6}{|c|}{ Response } \\
\hline & $X_{1}$ & $X_{2}$ & $\frac{w(\text { protein })^{*}}{\%}$ & $\frac{w(\text { solubility })^{*}}{\%}$ & $\frac{w(f a t)}{\%}$ & $\frac{\rho}{g / m L}$ & $\begin{array}{c}\text { Overrun } \\
\%\end{array}$ & $\frac{T_{m}}{\%}$ \\
\hline 1 & $-1(5)$ & $-1(10)$ & 8.4 & 40.89 & 16.66 & 0.8905 & 27.01 & 38.19 \\
\hline 2 & $1(15)$ & $-1(10)$ & 15.43 & 42.44 & 9.54 & 1.0609 & 5.28 & 0 \\
\hline 3 & $-1(5)$ & $1(20)$ & 6.33 & 39.75 & 13.81 & 0.817 & 25.81 & 36.2 \\
\hline 4 & $1(15)$ & $1(20)$ & 11.8 & 42.24 & 11.2 & 1.1783 & 5.3 & 0 \\
\hline 5 & $-1.41(2.95)$ & $0(15)$ & 5.12 & 38.98 & 17.56 & 0.8713 & 25.78 & 38.46 \\
\hline 6 & $1.41(17.05)$ & $0(15)$ & 15.61 & 43.41 & 13.62 & 1.132 & 25.72 & 0.9 \\
\hline 7 & $0(10)$ & $-1.41(7.95)$ & 11.13 & 41.54 & 9.9 & 1.0528 & 19.21 & 1.0 \\
\hline 8 & $0(10)$ & $1.41(22.05)$ & 10.28 & 41.28 & 18.9 & 1.1099 & 12.68 & 0 \\
\hline 9 & $0(10)$ & $0(15)$ & 8.73 & 40.93 & 15.23 & 1.12667 & 20.58 & 0.2 \\
\hline 10 & $0(10)$ & $0(15)$ & 10.29 & 41.28 & 15.28 & 1.1268 & 20.57 & 0.4 \\
\hline 11 & $0(10)$ & $0(15)$ & 9.51 & 41.11 & 15.26 & 1.1266 & 20.57 & 0.3 \\
\hline
\end{tabular}
and overrun of the soybean gelato formulations

$\mathrm{X}_{1}=$ soy protein concentrate $(\%), \mathrm{X}_{2}=$ hydrogenated fat $(\%)$, *expressed on dry mass basis 

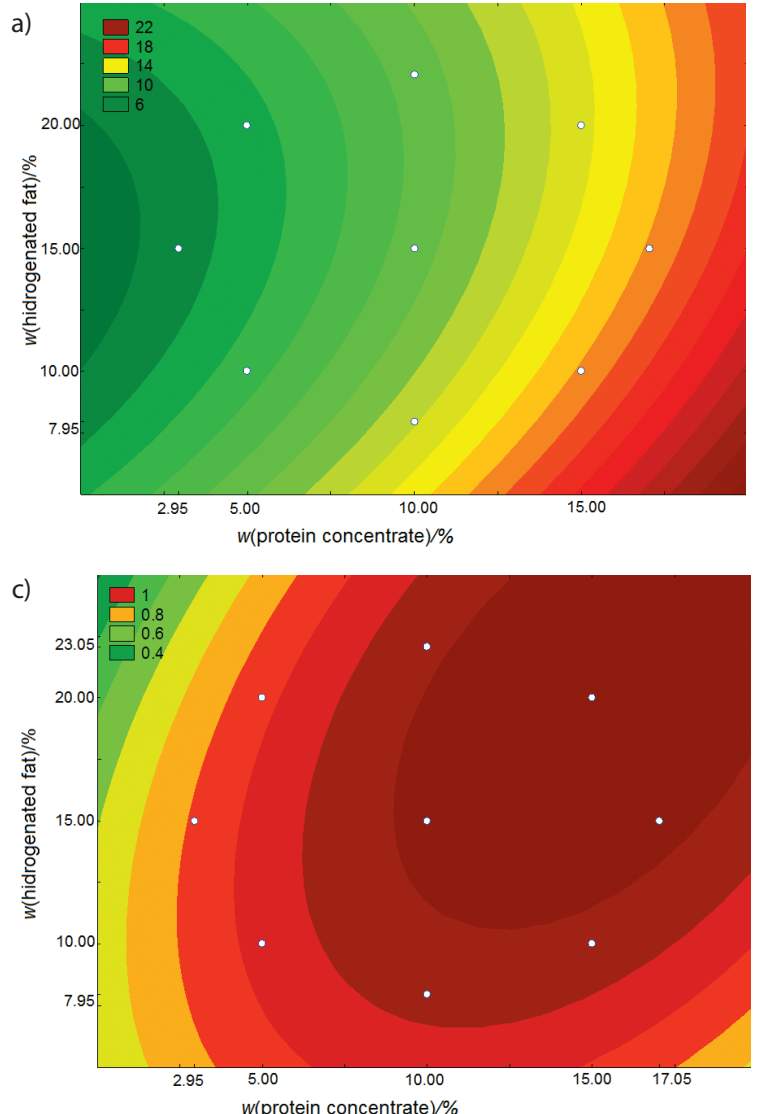
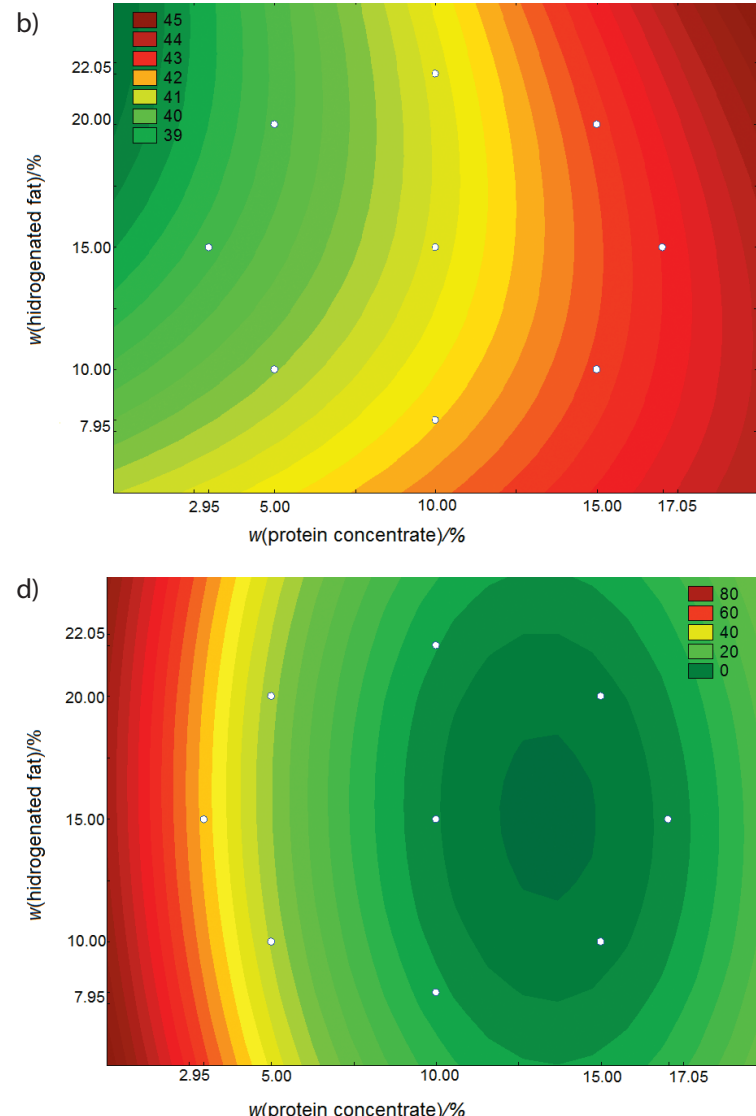

Fig. 1. Contour curves for: a) total protein content, b) solubility, c) density and d) melting point as a function of soybean protein concentrate and vegetable fat content in soybean gelato

homogenization, structure formation, and water retention capabilities, which improves the mixture viscosity, increases melting point and reduces ice formation (24).

Table 2 shows sedimentation, flotation, particle accumulation, and total protein destabilization values measured for gelato formulations. Destabilization was observed to occur by flotation and sedimentation. It was observed that the formulation from run 4 had the lowest destabilization, but with sedimentation. On the other hand, formulation 1 had a destabilization higher than formulation 4 , but without sedimentation, so it can be considered to have the best stability, while formulation 5 had the lowest stability, without sedimentation. The higher stability of the protein provided a better overrun and melting point (Table 1 and Table 2, Fig. 2).

We determined between 9.54 and $18.9 \%$ fat contents in gelato formulations. It was noted that the vegetable fat variables and the interaction between variables had a significantly positive effect at the $95 \%$ confidence level, whereas soybean protein concentrate had a negative effect $(p<0.05)$, showing that by increasing the vegetable fat mass per volume ratio and by interacting with the soybean protein concentrate, there is an increment on the formulation fat contents.

Specific mass (Table 1 ) of soybean gelato formulations ranged from 0.856 (run 5) to $1.12 \mathrm{~g} / \mathrm{mL}$ (run 6). Run 1 showed the highest overrun value.
Table 2. Sedimentation, flotation, particle accumulation, and total protein destabilization of the gelato formulations in measuring tubes

\begin{tabular}{|c|c|c|c|c|}
\hline Run & $\frac{\text { Sedimentation }}{\mathrm{mm}}$ & $\frac{\text { Flotation }}{\mathrm{mm}}$ & $\begin{array}{c}\begin{array}{c}\text { Particle } \\
\text { accumulation }\end{array} \\
\frac{\mathrm{mm}}{}\end{array}$ & $\frac{\text { Destabilization }}{\%}$ \\
\hline 1 & - & $10-65$ & $65-70$ & 21.9 \\
\hline 2 & $<25$ & $25-60$ & $60-70$ & 53.0 \\
\hline 3 & - & $10-60$ & $60-70$ & 63.4 \\
\hline 4 & $<15$ & $15-65$ & $65-70$ & 17.4 \\
\hline 5 & - & $10-60$ & $50-70$ & 77.1 \\
\hline 6 & $<17$ & $17-65$ & $65-70$ & 33.0 \\
\hline 7 & $<25$ & $25-70$ & - & 45.1 \\
\hline 8 & $<13$ & $13-62$ & $62-70$ & 33.0 \\
\hline 9 & $<13$ & $13-65$ & $65-70$ & 29.0 \\
\hline 10 & $<15$ & $15-60$ & $60-70$ & 21.5 \\
\hline
\end{tabular}

Eqs. 4, 5 and 6 give second-order coded models that described the specific mass, melting point and protein destabilization as a function of independent variables, within the studied ranges. The models were validated by the ANOVA with $0.97,0.93$ and 0.90 coefficient values and $F$ calculated values $6.14,2.84$ and 2.46 times greater than the $F$ tabulated ones, respectively. Was possible the construction of contour curves shown in Figs. 1c and 1d, respectively. It is observed that the maximum for specific mass and minimum for melting point was in the range close to $12 \%$ soybean protein concentrate and $15 \%$ hydrogenated vegetable fat addition, respectively. 


$$
\begin{array}{ll}
\rho=1.02+0.109 \cdot X_{1}-0.021 \cdot X_{1}{ }^{2}+0.012 \cdot X_{2}+0.013 \cdot X_{2}{ }^{2} & / 4 / \\
T_{\mathrm{m}}=0.266-15 \cdot X_{1}+11.89 \cdot X_{1}{ }^{2}-0.426 \cdot X_{2} & / 5 / \\
\text { Destabilization }=25.20-9.66 \cdot X_{1}+12.94 \cdot X_{1}{ }^{2}-19.27 \cdot X_{1} \cdot X_{2} & / 6 /
\end{array}
$$

where $T_{\mathrm{m}}$ is melting point, $\rho$ is density, $\mathrm{X}_{1}$ is soybean protein (\%) and $X_{2}$ is vegetable fat (\%).

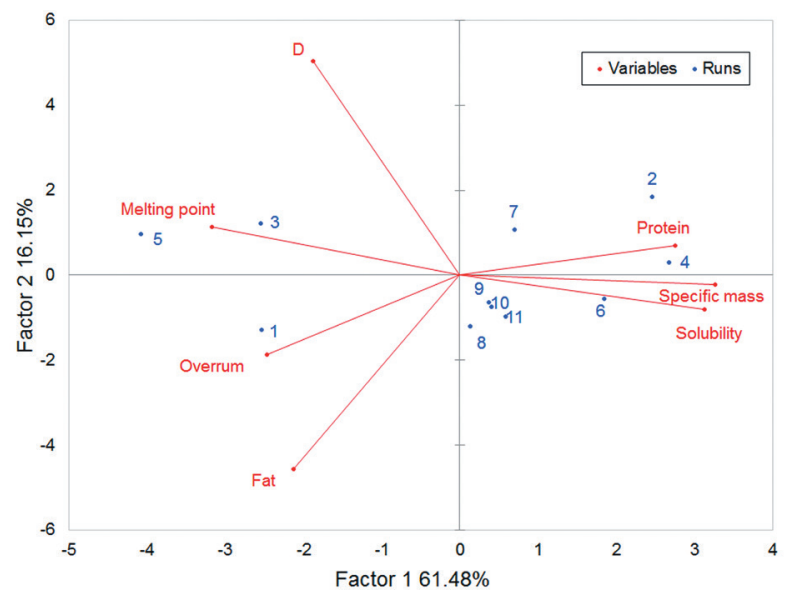

Fig. 2. Principal component analysis (PCA) of gelato formulations

The density of ice cream is directly related to air incorporation, i.e. the higher the air incorporation, the lighter the mass and thereby the lower this parameter value. Goff and Hartel (25) evaluated the elaboration of chocolate flavour ice cream formulations by verifying the effect of powdered milk and milky cream replaced with whey powder and alternative fat (Gay Lea, Guelph, Canada) and noted that some formulations showed values of density of approx. $0.475 \mathrm{~g} / \mathrm{mL}$. That could be due to whey proteins and alternative fat having functional properties that facilitate air incorporation, thus decreasing the density.

Cheaper ice creams usually contain more air than premium brand ones. One of the disadvantages of excessive air incorporation into ice creams is the tendency for it to melt more quickly. The amount of air also has a large effect on specific mass, where the best ice creams have a density of up to $0.90 \mathrm{mg} / \mathrm{L}$ (26).

Oliveira et al. (27) evaluated ice cream air incorporation (overrun) of soybean and verified $80 \%$ of overrun, and Passos et al. (28) found values of overrun close to the present study (29\%) in guava ice cream formulations.

The melting points of used formulations showed different characteristics among them, with two groups of similar melting point, one comprising formulations 1, 3 and 5, and the other formulations 2, 4, 6, 7 and 8 (Fig. 2). Formulations 1,3 and 5 showed $40 \%$ melting in the first $5 \mathrm{~min}$, distinctive from the other formulations that showed $3 \%$ melting in 50 min. Passos et al. (28) evaluated three different guava ice cream formulations and observed $100 \%$ melting point in 35 min. However, milk-based ice creams had 70 to $98 \%$ melting at times longer than 50 min (29).

Gelatos with high soy protein content are normally less stable; therefore, with a lower melting point. It was noted that formulations $2,4,6,7,8,9$ and 10 did not show a uniform and homogeneous melting due to their high protein and fat contents. High-quality ice cream must demonstrate limited resistance to melting when exposed to room temperature for a period of time. In this particular case, formulations 1, 3 and 5 showed limited resistance, promoting a considerable amount of time to start melting, showing clots and phase separation during the experiment, which is related to the high level of solids in formulations due to the high contents of soybean protein concentrate. Other factors that contribute to this behaviour are the excessive use of stabilizers/emulsifiers, high overrun, or even severe processing and interactions between components that promote highly stable gel formations (25).

There is a correlation between the variables observed in the analysis of principal components, where PC1 corresponded to $61.48 \%$ and PC2 to $16.15 \%$ of the total variance (Fig. 2). The protein had a positive correlation $(p<0.05)$ with solubility $(0.676)$ and density $(0.624)$ and negative $(p<0.05)$ with melting point $(-0.712)$ and fat content $(-0.586)$. There is a negative correlation, also, of the melting point with the solubility $(-0.743)$ and density $(-0.886)$, and positive with the destabilization of the protein content $(0.540)$ and overrun (0.592). However, the overrun had positive correction with the melting point (0.592) and fat content (0.508), and negative with density $(-0.738)$. The PCA (Fig. 2) also showed differentiation between the gelato formulations.

The results of structural analysis by X-ray diffraction of soybean gelato formulations is shown in Fig. 3 (formulations 1, 3, 5 and 9). Crystallinity patterns are established based on interplanar spacings and relative intensity of $\mathrm{X}$-ray diffraction lines (30), with gelato formulations showing similar behaviour; several main peaks near the $15^{\circ}$ and $35^{\circ}$ diffraction angles at $2 \Theta$, which characterized the crystalline part (formulations 1 , 3, 5 and 9 in Fig. 3; other formulations not shown). A-type pattern gave higher intensity peaks at $2 \Theta$ equal to $15^{\circ}, 17^{\circ}, 18^{\circ}$ and $23^{\circ}$, and $B$-type gave peaks at $2 \Theta$ equal to $5.6^{\circ}, 15^{\circ}, 17^{\circ}$, $22^{\circ}$ and $23^{\circ}$, where A-type pattern is more thermodynamically stable and denser than the B-type pattern, indicating greater cohesiveness between molecules (31). Soybean gelato formulations did not present peaks lower than $15^{\circ}$ at $2 \Theta$, characterized as an A-type pattern, demonstrating a tendency to cohesiveness between molecules.

Fig. 4 shows rheological behaviour (viscosity vs shear rate) of soybean gelato 1,3 and 5 at 10 and $20^{\circ} \mathrm{C}$. In general, soybean gelato formulations exhibited a non-Newtonian fluid behaviour. Such behaviour is linked to the nonlinear relationship between the shear rate and shear stress, in other words, a shear rate increase caused viscosity reduction in all analysed samples. Formulation 1 is more viscous (approx. $0.70 \mathrm{~Pa} \cdot \mathrm{s}$ at 10 ${ }^{\circ} \mathrm{C}$ and $1.00 \mathrm{~Pa} \cdot \mathrm{s}$ at $20^{\circ} \mathrm{C}$ ). This range of viscosity improved the overrun and the acceptability of the product. However, formulation 3, which had greater fat content, showed lower viscosity and formulation 5 had similar behaviour to formulation 3 , with values around $0.45 \mathrm{~Pa} \cdot \mathrm{s}$ at $10^{\circ} \mathrm{C}$ and $0.68 \mathrm{~Pa} \cdot \mathrm{s}$ at $20^{\circ} \mathrm{C}$. Oliveira et al. (27) observed that ice cream sample viscosity decreased with the shear rate, a behaviour also noted in this study. 
a)

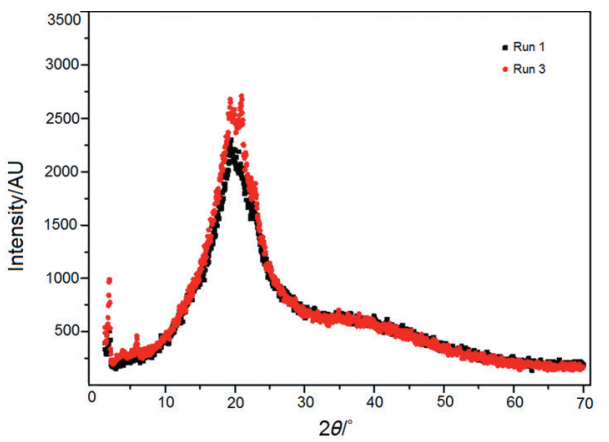

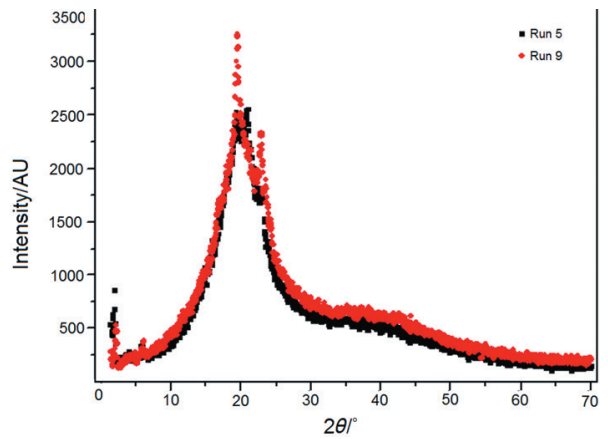

Fig. 3. Soybean gelato formulation diffractograms: a) formulations from runs 1 and 3 and b) from runs 5 and 9

a)

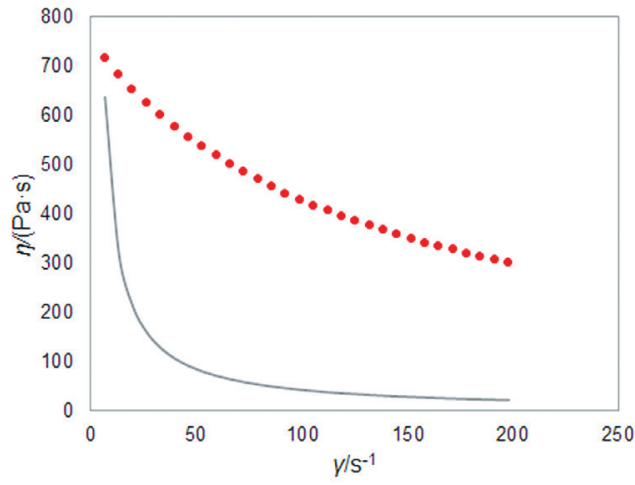

c)

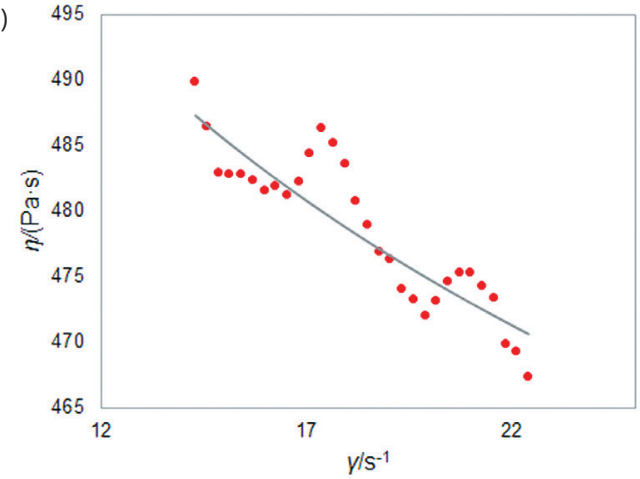

e)

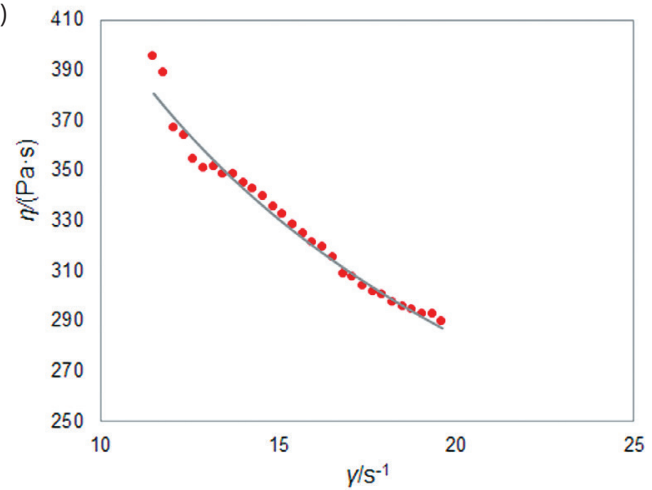

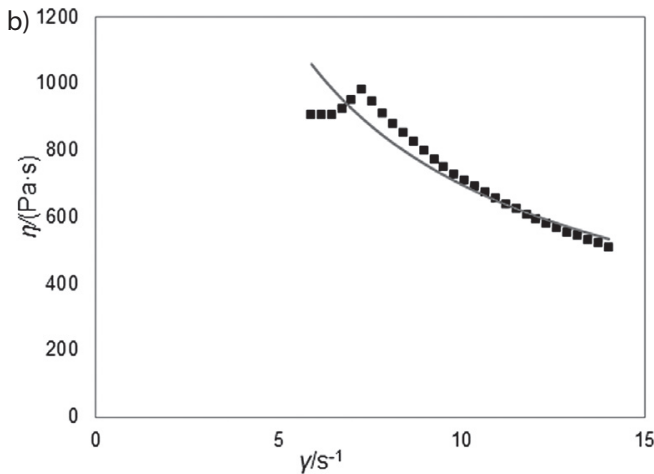
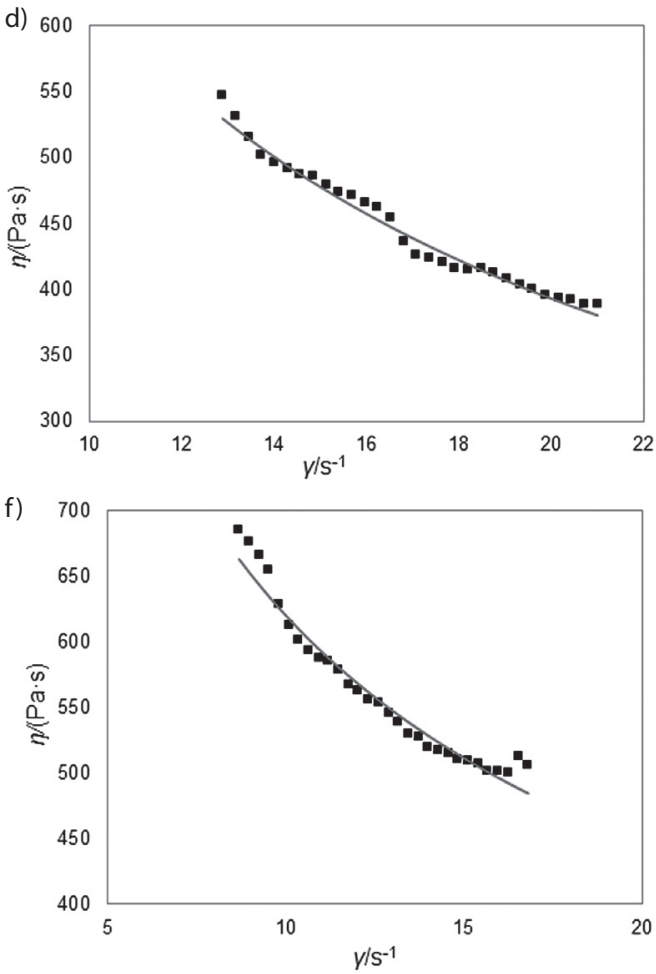

Fig. 4. Viscosity versus shear rate of soybean gelato: formulation 1 at a) $t=10$ and b) $t=20^{\circ} \mathrm{C}$, formulation 3 at c) $t=10$ and d) $t=20^{\circ} \mathrm{C}$, and formulation 5 at e) $t=10$ and f) $t=20^{\circ} \mathrm{C}$

Fig. 5 shows the traces of mass loss and its differential curves in the temperature range of $40-600^{\circ} \mathrm{C}$. The thermogravimetric analysis (TGA) curves for the formulations 1, 3 and 5 showed similar behaviour with four bands of mass loss.
It can be seen that there is a small loss of mass at temperatures below $100{ }^{\circ} \mathrm{C}$, which is due to the loss of moisture. The first band observed between $180-250{ }^{\circ} \mathrm{C}$ may be related to the loss of adsorbed and binding water. The second band 
observed between $250-400{ }^{\circ} \mathrm{C}$ corresponds to the decomposition of the soy protein and the fat/emulsifier of the formulation. The third band, observed between $400-460{ }^{\circ} \mathrm{C}$ and the fourth at $460-540^{\circ} \mathrm{C}$, may be associated with degradation of components (protein, fat and others).

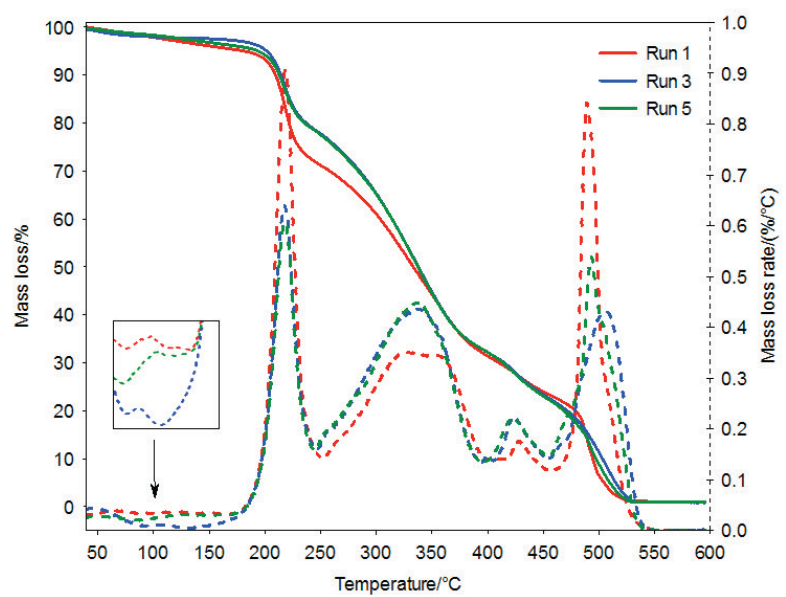

Fig. 5. Thermal analyses of gelato formulations from runs 1, 3 and 5 in temperature range of $40-600^{\circ} \mathrm{C}$

After evaluation of the melting points and rheological behaviour, the consumer acceptability of gelato formulations 1 , 3 and 5 was assessed (Table 3), with values of 80.55, 70.33 and $85.22 \%$, respectively. Formulations 1 and 5 did not differ statistically ( $p<0.05$ ), corresponding to the score scale of liked it and extremely liked it.

Table 3. Consumer acceptability of soybean gelato

$\begin{array}{ccc}\text { Run } & \text { Panellist score* } & \text { Acceptability/\% } \\ 1 & (7.25 \pm 1.34)^{\mathrm{a}} & (80.55 \pm 14.89)^{\mathrm{a}} \\ 3 & (6.33 \pm 0.62)^{\mathrm{b}} & (70.33 \pm 6.89)^{\mathrm{b}} \\ 5 & (7.67 \pm 1.12)^{\mathrm{a}} & (85.22 \pm 12.44)^{\mathrm{a}}\end{array}$

Mean values followed by the same lowercase letter in the same row did not differ significantly according to Tukey's test $(p<0.05)$. *According to the hedonic scale ( $9=$ =xtremely liked and $1=$ extremely disliked)

\section{CONCLUSIONS}

The replacement of milk with hydrosoluble extract and soybean protein concentrates proved to be an alternative for edible gelato preparation with distinguishing characteristics in terms of protein, solubility, viscosity, melting point and overrun, with consumer acceptability. The addition of up to $5 \%$ ( $\mathrm{m} / \mathrm{M}$ ) protein concentrate, $14 \%$ (by volume) soybean hydrosoluble extract, and $15 \%$ vegetable fat to gelato formulations resulted in better structural characteristics, with viscosity ranging from $0.45-0.70 \mathrm{~Pa} \cdot \mathrm{s}$ at $10^{\circ} \mathrm{C}$, a non-Newtonian behaviour, protein stability (total protein $8.44 \%$ and solubility $41 \%$ ). Soybean gelato structural analysis using $\mathrm{X}$-ray diffraction showed $15^{\circ}$ and $35^{\circ}$ diffraction angles at $2 \Theta$, characterizing the crystalline part of the product. The thermal analyses showed four bands of mass loss in the temperature range of $40-600^{\circ} \mathrm{C}$, characterizing loss of moisture, decomposition of the soy protein and the fat/emulsifier of the formulations. Therefore, replacing milk with soybean protein concentrate in gelato makes it an innovative, distinguish product with outstanding and specific characteristics. It is a lactose- and milk protein-free product that may be appreciated by the general public, and mainly, by the population with intolerance to such components.

\section{ACKNOWLEGMENTS}

The authors would like to thank the National Council for Scientific and Technological Development (CNPq), the Coordination for the Improvement of Higher Education Personnel (CAPES), the Research Support Foundation of Rio Grande do Sul State (FAPERGS) and Brazilian Agricultural Research Corporation (EMBRAPA).

\section{REFERENCES}

1. Ciabotti S, Barcelos MFP, Pinheiro ACM, Clemente PR, Lima MAC. Sensorial and physical characteristics of bleached and lipoxygenase-free soybean milk and curd. Ciênc Technol Aliment. 2007;27(3):643-8 (in Portuguese).

https://doi.org/10.1590/S0101-20612007000300033

2. Hwang JW, Do HJ, Kim OY, Chung JH, Lee JY, Park YS, et al. Fermented soy bean extract suppresses differentiation of 3T3-L1 preadipocytes and facilitates its glucose utilization. J Funct Foods. 2015;15:516-24.

https://doi.org/10.1016/j.jff.2015.04.002

3. Muliterno MM, Rodrigues D, de Lima DFS, Ida EL, Kurozawa LE. Conversion/degradation of isoflavones and color alterations during the drying of okara. LWT - Food Sci Technol. 2017;75:512-9.

https://doi.org/10.1016/j.lwt.2016.09.031

4. Schmidt JT, Cantelli K, Steffens C, Steffens J, Zeni J. Effects of vegetable coagulants in the production and storage of tofu. GI Sci Technol. 2017;10(1):188-98.

5. Biswas PK, Chakraborty R, Choudhuri UR. Effect of blending of soy milk with cow milk on sensory, textural and nutritional qualities of chhana analogue. J Food Sci Technol. 2017;39(6):702-4.

6. Kattan JD, Cocco RR, Järvinen KM. Milk and soy allergy. Pediatr Clin North Am. 2011;58(2):407-26.

https://doi.org/10.1016/j.pcl.2011.02.005

7. Bisla G, Poornima VA, Sharma SH. Development of ice creams from soybean milk and watermelon seeds milk and evaluation of their acceptability and nourishing potential. Adv Appl Sci Res. 2012;3(1):371-6.

8. Bowles S, Demiate IM. Physicochemical characterization of the soymilk by product - okara. Ciênc Tecnol Aliment. 2006; 26(3):652-9 (in Portuguese).

https://doi.org/10.1590/S0101-20612006000300026

9. Asif $M$, Acharya M. Phytochemicals and nutritional health benefits of soy plant. Int J Nutr Pharmacol Neurol Dis. 2013; 3(1):64-9. 
10. Da Silva LH, Celeghini RMS, Chang YK. Effect of fermentation of whole soybean flour in the isoflavone conversion from glycosides to aglycones. Food Chem. 2011;128(3):640-4. https://doi.org/10.1016/j.foodchem.2011.03.079

11. Paucar-Menacho LM, Berhow MA, Mandarino JMG, de Mejia EG, Chang YK. Optimization of germination time and temperature on the concentration of bioactive compounds in Brazilian soybean cultivar BRS 133 using response surface methodology. Food Chem. 2010;119(2):636-42. https://doi.org/10.1016/j.foodchem.2009.07.011

12. Pereira GD, De Resende JV, de Abreu LR, Giarola TMD, Perrone IT. Influence of the partial substitution of skim milk powder for soy extract on ice cream structure and quality. Eur Food Res Technol. 2011;232(6):1093-102. https://doi.org/10.1007/s00217-011-1483-z

13. Sutar N, Sutar PP, Singh G. Evaluation of different soybean varieties for manufacture of soy ice cream. Int J Dairy Technol. 2010;63(1):136-42.

https://doi.org/10.1111/j.1471-0307.2009.00557.x

14. Cheng J, Cui J, MaY, Yan T, Wang L, Li H, Li X. Effects of soy-to-milk protein ratio and sucrose fatty acid ester addition on the stability of ice cream emulsions. Food Hydrocoll. 2016; 60:425-36.

https://doi.org/10.1016/j.foodhyd.2016.04.002

15. Mandarino JMG, Benassi VDT, Carrão-Panizzi MC. Manual of soybean recipes. In: Documents 206. Londrina, PR, Brazil: Embrapa Soja. 2003 (in Portuguese).

16. Maia MCA, Galvão APGLK, Modesta RCD, Pereira Júnior N. Consumer evaluation of ice cream with xylitol. Ciênc Tecnol Aliment. 2008;28(2):341-7 (in Portuguese).

https://doi.org/10.1590/S0101-20612008000200011

17. AOAC Official method 991.22. Protein nitrogen content of milk - Kjeldahl method. Rockville, MD, USA:The Association of Official Analytical Chemists (AOAC); 2000.

18. Lowry $\mathrm{OH}$, Rosebrough NJ, Farr AL, Randall RJ. Protein measurement with the Folin phenol reagent. J Biol Chem. 1951;193(1):265-75.

19. Granger C, Leger A, Barey P, Langendorff V, Cansell M. Influence of formulation on the structural networks in ice cream. Int Dairy J. 2005;15(3):255-62. https://doi.org/10.1016/j.idairyj.2004.07.009

20. Plataforma Brasil. Avaliable from: http://aplicacao.saude. gov.br/plataformabrasil.
21. Statistica v. 5.0. Tulsa OK, USA: StatSoft, Inc; 2012. Avaliable from: http://www.stasoft.com.

22. Zayas JF. Functionality of proteins in food. Berlin, Germany: Springer-Verlag; 1997.

https://doi.org/10.1007/978-3-642-59116-7

23. Silveira Queiroz HG, Sampaio Neta NA, Sales Pinto R, Passos Rodrigues MC, Correia da Costa JM. Evaluation of the physical-chemical and microbiological quality of tapioca ice cream. Rev Ciênc Agron. 2009;40(1):60-5. (in Portuguese).

24. Souza JCB, Costa MR, De Rensis CMVB, Sivieri K. Ice cream: Composition, processing and addition of probiotic. Aliment Nutr. 2010;21:153-63. (in Portuguese).

25. Goff HD, Hartel, RW. Mix processing and properties. In: Goff HD, Hartel RW, editors. Ice cream. Switzerland: Springer Nature; 2013. pp. 12154.

https://doi.org/10.1007/978-1-4614-6096-1_5

26. Rodrigues AP, Fontana CV, Padilha E, Silvestrin M, Augusto MMM. Elaboration of ice cream with chocolate flavor with reduced fat content using whey powder. Vetor. 2006;16:5562 (in Portuguese).

27. Oliveira KH, De Souza JAR, Monteiro AR. Rheological characterization of ice cream. Ciênc Tecnol Aliment. 2008;28(3): 592-8 (in Portuguese).

https://doi.org/10.1590/S0101-20612008000300014

28. Passos AAC, Sá DMAT, De Morais GMD, Chacon LSS, Braga RC. Evaluation of the incorporation of Caesalpinia pulcherrima galactomannan in ice cream and comparison with commercial stabilizers. Rev Ciênc Agron. 2016;47:275-82 (in Portuguese).

https://doi.org/10.5935/1806-6690.20160032

29. Fiol C, Prado D, Romero C, Laburu N, Mora M, Iñaki Alava J. Introduction of a new family of ice creams. Int J Gastr Food Sci. 2017;7:5-10. https://doi.org/10.1016/j.ijgfs.2016.12.001

30. Zobel HF. X-ray analysis of starch granules. In: Methods in carbohydrate chemistry, vol. IV Starch. Whistler RL, Smith RJ, Wolfrom ML, BeMiller JN, editors. New York, NY, USA: Academic Press; 1964. pp. 109-13.

31. Teixeira MAV, Ciacco CF, Tavares DQ, Bonezzi AN. Occurence and caracterization of resistant starch from corn and banana starch. Ciênc Tecnol Aliment. 1998;18(2):246-53 (in Portuguese).

https://doi.org/10.1590/S0101-20611998000200019 